METHODOLOGY, RESULTS, AND SIGNIFICANCE OF AN UNSATURATED-ZONE TRACER TEST AT AN ARTIFICIAL-RECHARGE FACILITY, TUCSON, ARIZONA

By D.D. Graham

U.S. GEOLOGICAL SURVEY

Water-Resources Investigations Report 89-4097

Prepared in cooperation with the CITY OF TUCSON 
DEPARTMENT OF THE INTERIOR

MANUEL LUJAN, JR., Secretary

U.S. GEOLOGICAL SURVEY

Dallas L. Peck, Director

For additional information write to:

District Chief

U.S. Geological Survey Federal Building, FB-44 300 West Congress Street

Tucson, Arizona 85701-1393
Copies of this report can be purchased from:

U.S. Geological Survey Books and Open-File Reports Section Federal Center, Building 810 Box 25425

Denver, Colorado 80225 


\section{CONTENTS}

Page

Abstract.............................................. 1

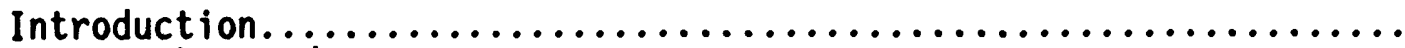

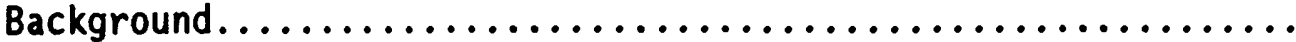

Purpose and scope.

Description of study area and test site.

Physical setting.

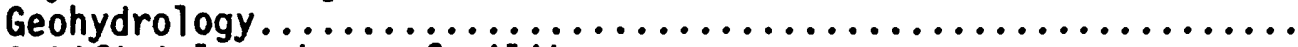

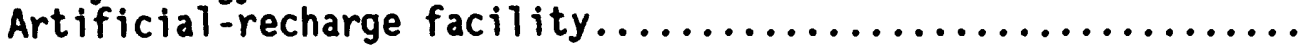

Unsaturated-zone sampling.

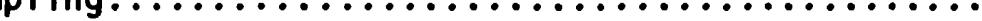

Lysimeters....

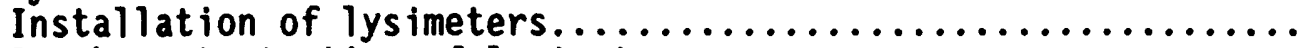

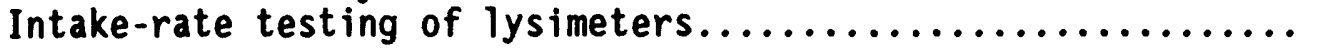

Unsaturated-zone tracer test............................

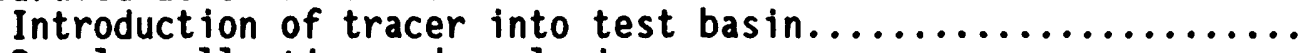

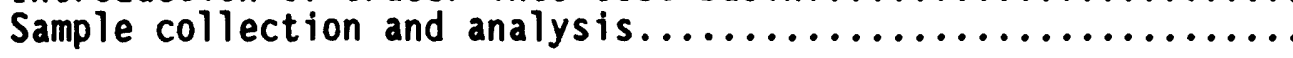

Results of study......................................... 15

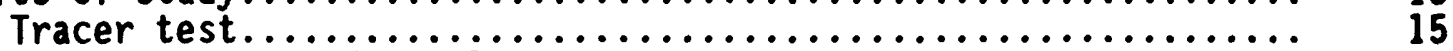

Interpretation of resuits $\ldots \ldots \ldots \ldots \ldots \ldots \ldots \ldots \ldots \ldots \ldots \ldots \ldots \ldots \ldots \ldots \ldots \ldots, 18$

Significance of results............................... 23

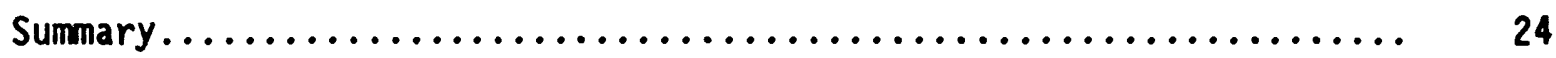

Selected references.................................. 25

\section{ILLUSTRATIONS}

Page

Figure 1. Map showing location of study area in Tucson basin, southeastern Arizona, and major features of the Tucson Water Demonstration Recharge Facility.......

2. Drawing showing pressure-vacuum lysimeters used in tracer test................................. 
IV

Figures 3-4. Graphs showing: Page

3. Concentration of bromide $\left(8 r^{-}\right)$in basin 4

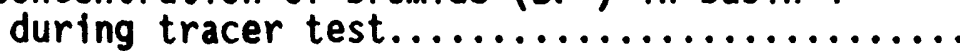

16

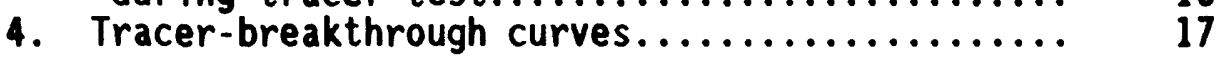

5. Drawing showing cross section of model tank showing water movement as a wetting front and along preferential-flow paths through layered glass

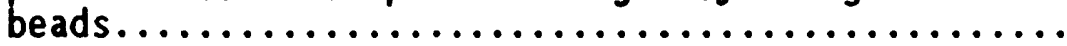

6. Graph showing distribution of average velocity from tracer-breakthrough curves with depth in

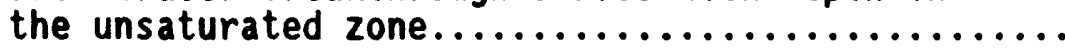

TABLES

Page

Table 1. Geologic and hydrologic units in the Tucson area and their hydrologic significance.............

2. Sample volumes extracted from lysimeters during

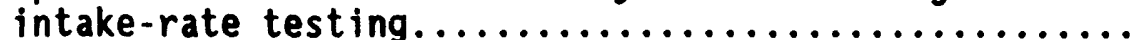

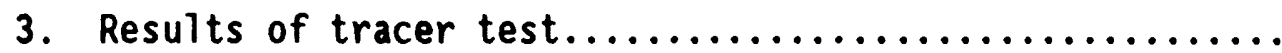

For readers who prefer to use metric (International System) units, rather than the inch-pound terms used in this report, the following conversion factors may be used:

Multiply inch-pound unit

inch (in.)

ounce, fluid (fl oz)

foot ( $f t)$

mile (mi)

square mile $\left(\mathrm{mi}^{2}\right)$

pound ( $1 \mathrm{~b})$

gallon (gal)

gallon per minute (gal/min)

degree Fahrenheit ( $\left.{ }^{\circ} \mathrm{F}\right)$

pound per square inch $\left(1 \mathrm{~b} / \mathrm{in}^{2}\right)$
By

25.4

29.57

0.3048

1.609

2.590

0.4536

3.785

0.06308

${ }^{\circ} \mathrm{C}=5 / 9\left({ }^{\circ} \mathrm{F}-32\right)$

6.895
To obtain metric unit

millimeter (mm)

milliliter $(\mathrm{mL})$

meter (m)

kilometer (km)

square kilometer $\left(\mathrm{km}^{2}\right)$

kilogram (k)

liter (L)

liter per second $(L / s)$

degree Celsius $\left({ }^{\circ} \mathrm{C}\right)$

kilopascal (kPa) 


\title{
METHODOLOGY, RESULTS, AND SIGNIFICANCE OF AN UNSATURATED-ZONE TRACER TEST AT NN ARTIFICIAL-RECHARGE FACILITY, TUCSON, ARIZONA
}

\author{
By
}

D.D. Graham

\begin{abstract}
A tracer test conducted in March and April of 1987 at an artificial-recharge facility operated by the City of Tucson in Tucson, Arizona, indicates that solute movement through the poorly sorted stratified alluvial sediments in the unsaturated zone beneath a recharge basin takes place along preferential-flow paths. The movement of a tracer-laced pulse of reclaimed wastewater was monitored in the unsaturated zone using pressure-vacuum lysimeters installed at depths that range from 11 to 45 feet below the bottom of a recharge basin. Bromide was used as the tracer. Tracer-breakthrough curves do not indicate a consistent relation between maximum tracer concentration and depth or between time of tracer breakthrough and depth. Apparent dispersion, as indicated by the slope of the rising leg of the tracer-breakthrough curve, shows no apparent relation with depth. In some cases, tracer arrival occurred earlier at deep sampling locations than at shallow ones. Velocity of solute flow, computed from time of first tracer arrival, ranged from 1.9 to 9.0 feet per day.

Less interaction between recharge water and solid-phase materials in the unsaturated zone occurs under preferential-flow conditions than if flow occurred as a uniform wetting front. Flow of water through the unsaturated zone is concentrated into fingers or channels under preferential-flow conditions, and the renovating capability of soil is reduced because of the reduced surface area and reduced contact time in the biologically active part of the unsaturated profile. Chemical substances that normally would be decomposed by microbial activity or sorbed by sediment particles can move through the unsaturated zone and cause ground-water contamination under preferential-flow conditions.
\end{abstract}

\section{INTRODUCTION}

Throughout most of Tucson basin and in many other alluvial basins in Arizona, depth to ground water exceeds $100 \mathrm{ft}$. The unsaturated zone in much of Tucson bas in is composed of thick sequences of poorly sorted alluvial sediments. Ground-water contaminants may be sorbed, degraded, or transmitted as water passes through these sediments. Naturally occurring soluble salts or manmade contaminants that may have accumulated in the unsaturated sediments could be mobilized by activities that occur at the land surface, such as ponding to induce artificial recharge. An investigation was conducted in 1987-88 by the U.S. 
Geological Survey, in cooperation with the City of Tucson, to determine the characteristics of solute movement through the unsaturated zone. The investigation was done at an artificial-recharge facility operated by the City of Tucson in Tucson, Arizona (fig. 1).

\section{Background}

Several instances of ground-water contamination have been documented in Arizona. In 1981, ground water from municipal and private wells near the Tucson International Airport was found to be contaminated by the organic solvent trichloroethylene (TCE), other organic compounds, and chromium. At this location, a plume $4 \mathrm{mi}$ long and more than $0.5 \mathrm{mi}$ wide has been delineated in which TCE concentrations exceed U.S. Environmental Protection Agency drinking-water standards (U.S. Environmental Protection Agency, 1988; Leake and Hanson, 1987). At another location near the Phoenix-Goodyear Airport (formerly Phoenix-Litchfield Airport), concentrations in ground water of TCE of about 86,000 micrograms per liter $(\mu \mathrm{g} / \mathrm{L}), 1,1$-dichloroethylene (DCE) of about $241 \mu \mathrm{g} / \mathrm{L}$, and chromium of about 1,300 $\mu \mathrm{g} / \mathrm{L}$ have been reported (Ecology and Environment, Inc., 1986). In both locations, contamination occurred despite a depth to ground water of about $100 \mathrm{ft}$. Incidents such as these have increased public awareness of the need to protect ground-water quality. Protection of ground-water quality is complex and requires information about al1 components of the hydrologic system. Potential sources of ground-water contamination commonly are at or near the 1 and surface and are separated from the underlying ground-water aquifer by the unsaturated zone.

\section{Purpose and Scope}

The purpose of this report is to describe the methods, results, and significance of a tracer test conducted to monitor the movement of water through the unsaturated zone beneath an artificial-recharge basin. Characteristics of flow through the unconsolidated to semiconsolidated, poorly sorted, alluvial sediments that constitute the unsaturated zone in Tucson basin were identified to improve understanding of the potential for ground-water contamination and the controlling factors on downward movement of recharge water. The sediments that constitute the unsaturated zone in Tucson basin are similar to those found in alluvial basins throughout the Basin and Range physiographic province. The results of this study are applicable to arid and semiarid regions where the unsaturated zone is thick.

A tracer test was conducted to monitor the movement of a tracer-laced pulse of water as it passed through the unsaturated zone beneath a 3/4-acre recharge basin. Water samples were collected from the unsaturated zone using six porous-cup lysimeters, which were installed at depths that range from 11 to $45 \mathrm{ft}$. Tracer-breakthrough curves depicting the relation of tracer concentration to time were analyzed to determine the rates of movement of the tracer at each sampling location and to 


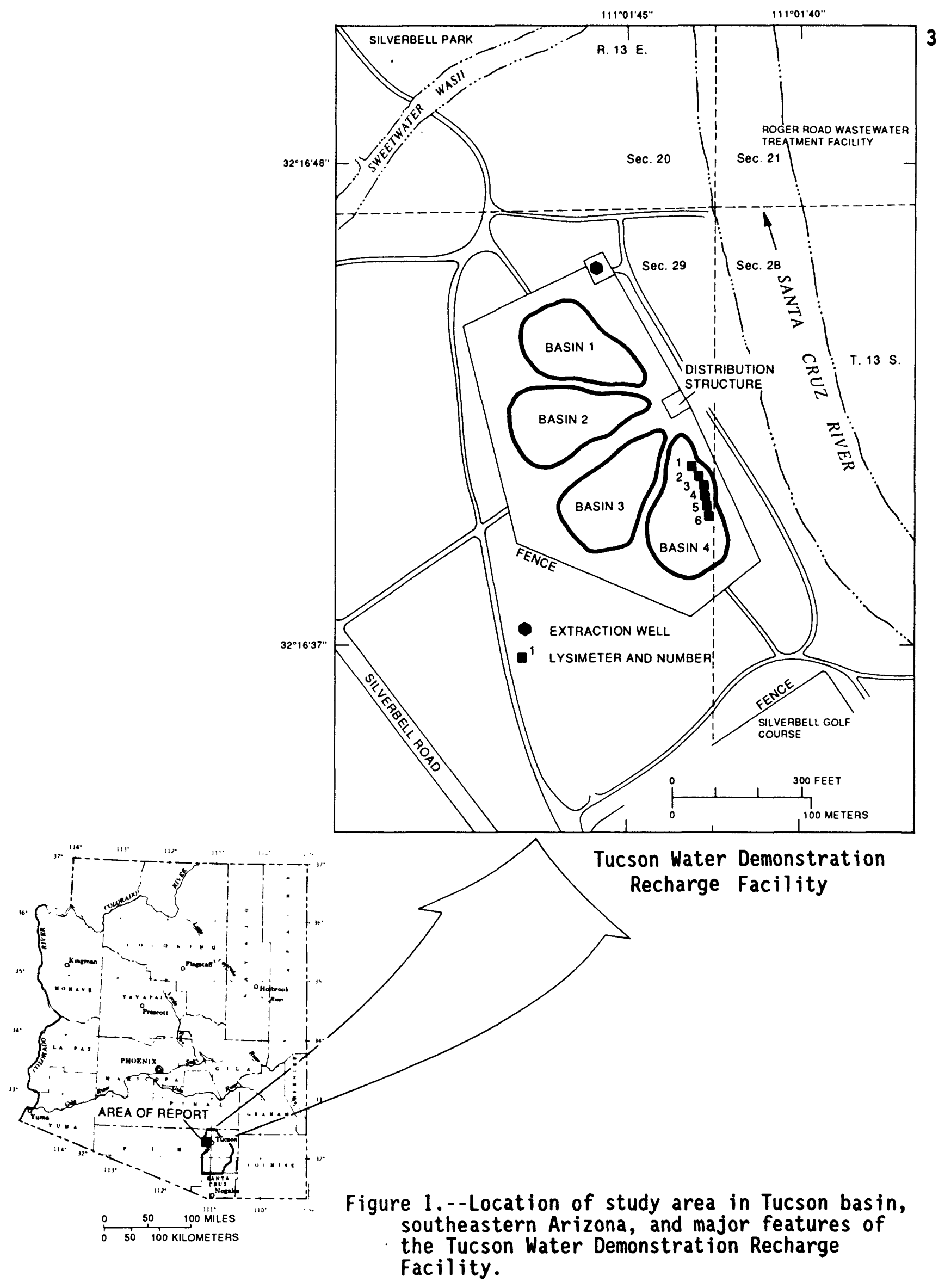


provide information about the characteristics of flow through the heterogeneous sediments.

\section{DESCRIPTION OF STUDY AREA NND TEST SITE}

\section{Physical Setting}

The investigation was conducted in one of the recharge basins of the Tucson Water Demonstration Recharge Facility. The facility is on the flood plain of the Santa Cruz River at Tucson in the northwestern part of Tucson basin in Pima County, southeastern Arizona (fig. 1). Tucson basin is a broad sediment-filled structural depression in the Basin and Range physiographic province (Fenneman, 1931). Tucson basin is 15 to 20 mi wide in the southern and central parts, about 4 mi wide at the northwest outlet, and about $50 \mathrm{mi}$ long. Tucson basin is drained to the northwest by the Santa Cruz River and its major tributaries-Rillito Creek and Canada del Oro. All major surface drainages are ephemeral.

Tucson basin is bounded by mountains that restrict inflow and outflow of ground water. The basin is underlain by several thousand feet of unconsolidated and semiconsolidated sediments of fluvial origin. The channels of the main streams are entrenched in alluvium that consists of unconsolidated to semiconsolidated clay, silt, sand, and gravel. The alluvium ranges from about 20 to $100 \mathrm{ft}$ in thickness (Davidson, 1973; Laney, 1972).

Mean annual precipitation is 11 to 12 in. in the central part of Tucson basin (Sellers and others, 1985). Precipitation throughout the year is extremely variable. From July through September, most precipitation occurs as intense, localized thunderstorms. From December through March, frontal storms produce widespread precipitation in large parts of the basin. Ordinarily, the precipitation that occurs during the winter months is less intense but of longer duration than summer precipitation. Most ground-water recharge in Tucson bas in is derived from infiltration along the major stream channels and from mountain-front recharge that generally occurs during the winter months (Davidson, 1973).

\section{Geohydrology}

In Tucson basin, unconsolidated to semiconsolidated sedimentary deposits that are more than 2,000 ft thick in the center of the basin form a single, hydraulically continuous aquifer system (table 1). Locally discontinuous clay lenses may act as confining layers that restrict vertical flow within the aquifer (Mock and others, 1985). The thickness of the unsaturated zone in Tucson basin ranges from 25 to $700 \mathrm{ft}$. The unsaturated zone is thinnest along the Santa Cruz River and in the northern part of the basin and is thickest in the southeastern part. Throughout most of Tucson basin, the thickness of the unsaturated zone exceeds $100 \mathrm{ft}$ (Davidson, 1973, pl. 4a). In the unsaturated zone above 


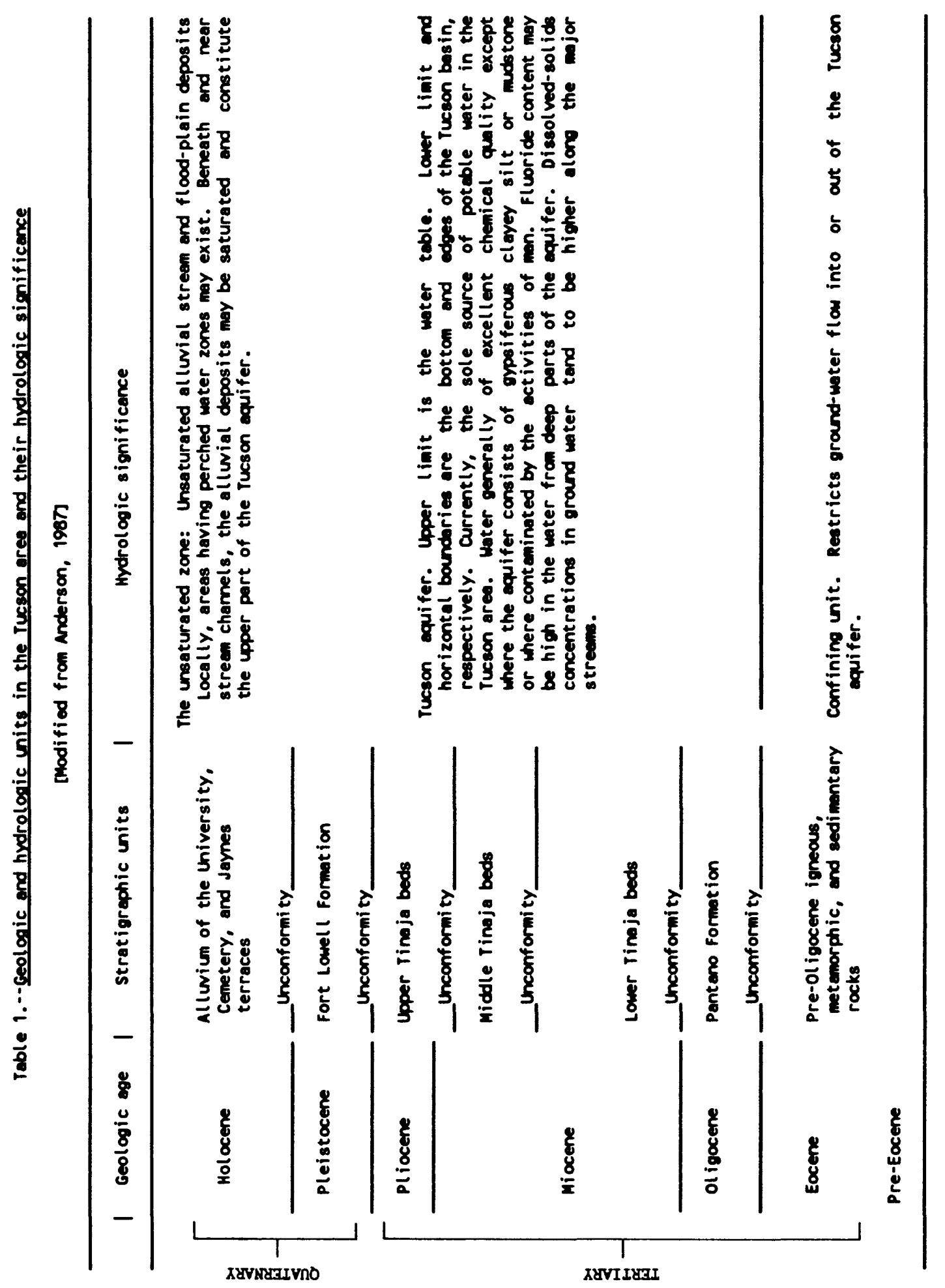


the Tucson aquifer, perched ground-water zones exist in parts of the basin (Hargis and Montgomery, 1982a, b; Mock and others, 1985). Deposits that constitute the Tucson aquifer range from Tertiary to Quaternary in age. The principal stratigraphic units of the Tucson aquifer are the Pantano Formation of 01 igocene age, the Tinaja beds of Miocene and Pliocene age, and the Fort Lowell Formation of Pleistocene age (Davidson, 1973). A thin veneer of stream alluvium and sheetflow deposits of late Quaternary age overlies the Fort Lowell Formation. Anderson (1987) provides a thorough review of Cenozoic stratigraphic relations and the geologic history of Tucson basin.

Tucson basin is surrounded by mountains that consist of essentially impermeable crystalline intrusive and metamorphic rocks, slightly permeable to highly permeable volcanic rocks, and slightly permeable to moderately permeable sedimentary rocks of pre-01igocene age. The rocks that form the mountains along the margin of the basin and the rocks that underlie the sediment-filled basin restrict inflow and outflow of ground water. The bedrock that forms the mountain ranges and the bottom of Tucson basin is considered to be almost impermeable, although there are springs at the base of some of the mountains and low-yielding wells have been completed in rocks of the mountains. Additional information about the lithology and water-bearing properties of the bedrock that forms the margins of Tucson basin is given by Davidson (1973).

The Tucson aquifer is designated as a sole-source water supply (U.S. Environmental Protection Agency, 1984) and provides all the water for municipal, private, industrial, and agricultural use in the Tucson area. Most water from the aquifer contains less than 500 milligrams per liter $(\mathrm{mg} / \mathrm{L})$ of dissolved solids and is of suitable chemical quality for most uses. The ground water of poorest quality occurs at shallow depths along the major streams along the northeast margin of the basin and at greater depths where it passes through gypsiferous mudstone. Ground water from a depth greater than about $1,000 \mathrm{ft}$ locally may contain large concentrations of fluoride. A review of basin-wide variations in ground-water chemistry is given by Laney (1972). In some areas of Tucson basin, such as parts of southwest Tucson and the northeastern part of the San Xavier Indian Reservation, use of ground water for public supply is restricted by the occurrence of manmade contaminants. These contaminants may include trichloroethylene (TCE), dichloroethylene (1,1-DCE), chloroform, benzene, xylene, and chromium (Leake and Hanson, 1987; U.S. Environmental Protection Agency, 1988).

\section{Artificial-Recharge Facility}

The Tucson Water Demonstration Recharge Facility (fig. 1) is operated by the City of Tucson for aquifer storage and reuse of filtered, disinfected sewage effluent (reclaimed water). Reclaimed water is distributed throughout the community for turf irrigation uses. The supply of effluent generally is almost constant throughout the year, but irrigation demand has a monthly variation of as much as 300 percent (Randall and Johnson, 1985). The artificial-recharge facility provides a capability for seasonal storage of reclaimed water and subsequent recovery 
and use during periods of peak demand. The aquifer is recharged with reclaimed water through the use of infiltration basins. Recovery of recharged effluent is accomplished by use of an extraction well downgradient from the infiltration basins. Water generaliy is recharged during the fall and winter and recovered during the spring and summer.

Seasonal aquifer storage minimizes the capital costs associated with the production and storage of reclaimed water. Turf irrigation with reclaimed water has reduced peak demands on the municipal potable-water delivery system (Johnson, 1987). In addition to these water-management benefits, the Tucson Water Demonstration Recharge Facility functions as a test site for evaluation of artificial-recharge techniques and for a variety of scientific investigations.

The primary features of the Tucson Water Demonstration Recharge Facility are four, irregularly shaped, 3/4-acre infiltration basins on the west side of the Santa Cruz River channel (fig. 1). The basins are surrounded by compacted soil dikes that are $3 \mathrm{ft}$ high. Reclaimed water is supplied by means of a pipeline from a treatment plant on the east side of the river channel directly opposite the recharge facility. A distribution system at the recharge facility provides water to each of the basins. As the water is being recharged, a constant depth is maintained in the basins by float-operated sensors and solenoid-actuated valves that independently regulate the flow of water to each basin. Normal operating depth ranges between 1.65 and $1.90 \mathrm{ft}$.

Depth to the water table in the area of the recharge facility ranges from 105 to $110 \mathrm{ft}$. The recharge basins are underlain by stream alluvium. In the upper part of the unsaturated zone at the recharge facility, the sediments consist of stratified deposits of silty sand with minor discontinuous silty clay laminae, which ranges from 0 to $10 \mathrm{ft}$ below land surface; in some locations, this layer is absent. Silty or clayey sands and gravels range from 0 to $30 \mathrm{ft}$ below land surface; and silty sands and gravels range from a depth of about $30 \mathrm{ft}$ below land surface to below the water table. Discontinuous horizontal lenses and interbeds of sandy clay and poorly sorted sand, gravel, cobbles, and boulders are found throughout the sequence.

\section{UNSATURATED-ZONE SAMPLING}

In the unsaturated zone, soil moisture is stored in the small capillary voids between the soil particles and on the surfaces of the soil particles. Moisture in unsaturated soil is held in the capillary voids at pressures below atmospheric pressure. To remove moisture from unsaturated soil, suction is needed to overcome capillary tension. Soil suction is low in wet soils and high in dry soils. The procedures used for obtaining soil-moisture samples differ from those used for obtaining water samples from below the water table. A thorough review of unsaturated-zone sampling techniques and instrumentation is given by U.S. Environmental Protection Agency (1986). Everett and McMillion (1985) compared the performance characteristics and operational ranges of several types of soil-moisture samplers. Robbins and Gemmell (1985) reviewed some of the 
factors that need to be considered in installing an unsaturated-zone monitoring system.

\section{Lysimeters}

An array of six pressure-vacuum lysimeters (fig. 2) was used to collect water from the unsaturated zone underlying the recharge facility. The six lysimeters were installed in bas in 4, along the eastern edge (fig. 1) and were approximately $10 \mathrm{ft}$ apart and about $10 \mathrm{ft}$ from the edge of the basin. The lysimeters were positioned to minimize disruption to basin-maintenance activities and were spaced to avoid cross interference.

The intake section of a pressure-vacuum lysimeter consists of a round-bottom porous ceramic cup. Suction is used to collect a sample from the unsaturated sediments that surround the ceramic cup. Samples are obtained by removing air with a hand-operated pump to create a partial vacuum in the lysimeter. If the pressure in the sampler is lower than the soll tension in the surrounding sediments, water will tend to move into the sampler. Positive pressure is used to $11 \mathrm{ft}$ the sample to the surface after allowing enough time to elapse for sufficient sample to enter the sampler through the ceramic cup. A good hydraulic connection is essential between the formation and the porous cup to collect moisture samples from unsaturated sediments. Fine-grained silica flour was installed as a slurry in the annular space surrounding the ceramic cup to establish this connection. The resulting envelope of silica flour that surrounds the ceramic cup may extend the sampling area and allow more water to be intercepted. The silica flour also helps to prevent clogging of the pores of the ceramic cup.

In order to obtain water samples from porous-cup lysimeters installed at depths below the limit of suction lift, pressure is used to lift the sample to the surface. Where samples are collected from depths of about $50 \mathrm{ft}$, the pressure required to $1 \mathrm{ift}$ the sample to the surface may force the sample back into the ground through the intake section. To avoid this problem, a modified lysimeter equipped with separate sample and vacuum lines and two stainless-steel check valves has been devised (fig. 2).

Overpressurizing the ceramic cup during sample retrieval would force some or all of the sample back into the formation and may disrupt the hydraulic connection between the ceramic cup and the surrounding materials. The function of the lower check valve (fig. 2) is to isolate the main sample chamber from the intake section to prevent overpressurization of the ceramic cup. The function of the upper check valve (fig. 2) is to el iminate sample backpressure and keep water from draining back into the lysimeter from the sample line. These check valves allow samples to be obtained from great depths with minimal pumping effort.

The body of the lysimeter is constructed of polyvinylchloride (PVC) pipe. The lysimeter is $2 \mathrm{ft}$ long and has an outside diameter (0.D.) of $1.9 \mathrm{in}$. The sample and vacuum lines consist of $1 / 4-$ inch $0 . \dot{D}$. polyethylene tubing attached to the lysimeter with standard pressure fittings. A short length of neoprene tubing and a pinch clamp are attached to each line at the land surface. 


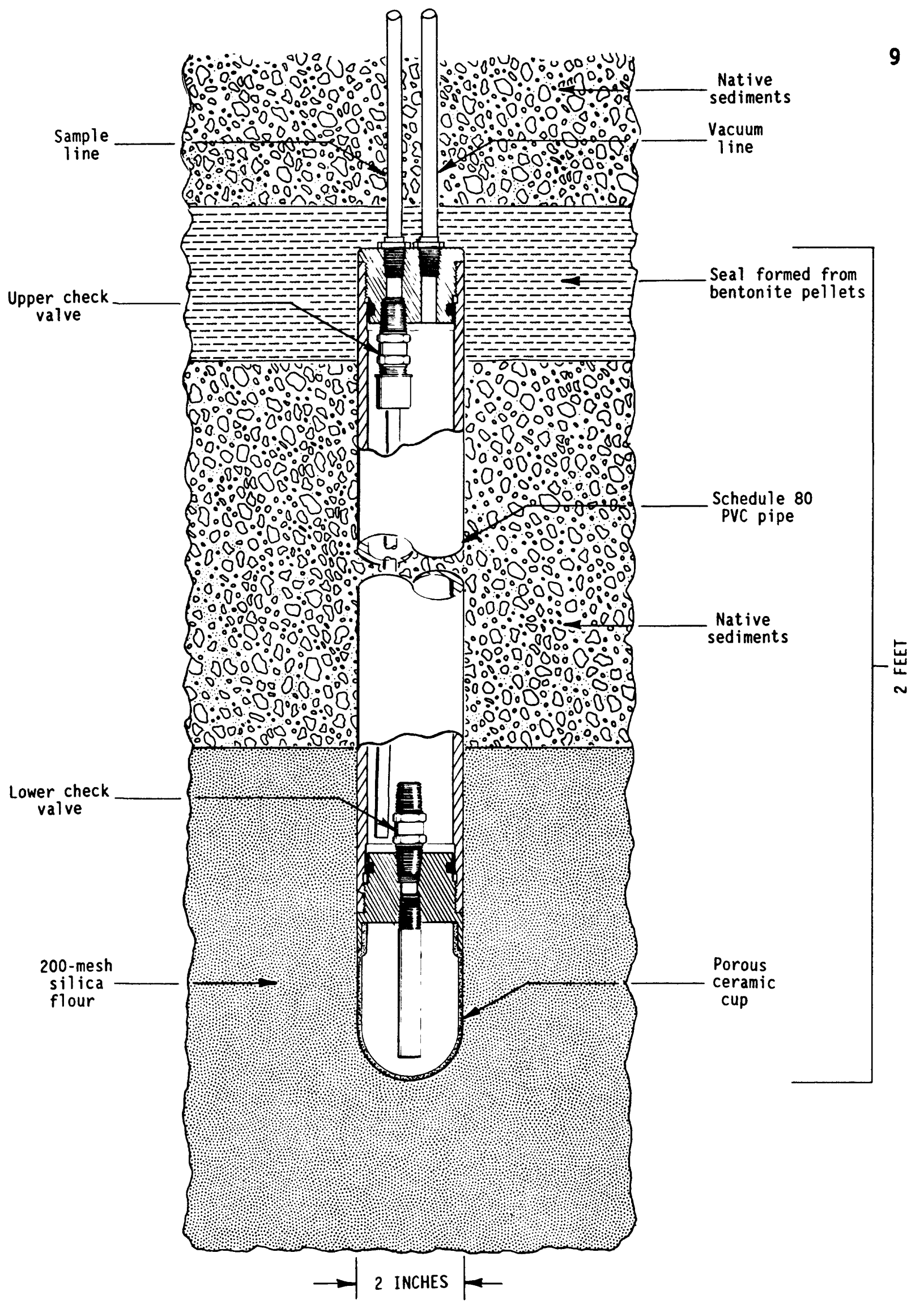

Figure 2.--Pressure-vacuum lysimeters used in tracer test. 


\section{Installation of Lysimeters}

The lysimeters were installed with a hollow-stem auger drilling rig at depths that range from 11 to $45 \mathrm{ft}$ below the bottom of the recharge basin:

\begin{tabular}{lrrrrrr} 
Lysimeter......... & 1 \\
Depth, in feet..... & 40 & 28 & 11 & 27 & 13 & 45 \\
\hline
\end{tabular}

Drilling and emplacement of lysimeters took place in November 1986 when the bas in was empty and the bas in bottom was completely dry. To minimize damage to the basin bottom and surrounding berms, portable steel tracking was used when the drilling rig was moved into and out of the basin and from one drilling location to the next within the basin. The general procedures used for installing the lysimeters are as follows:

1. A hole was augered to the desired depth using a 6-in. 0.D., 3.5-in. I.D. (inside diameter) hollow-stem auger.

2. The auger was raised about $2 \mathrm{ft}$ from the bottom of the hole.

3. Approximately 20 lbs of silica flour was mixed with water and installed as a slurry at the bottom of the hole through a tremie pipe.

4. The lysimeter was pressure tested to confirm the operation of the check valves and the integrity of all connections, and then it was lowered into the silica flour through the hollow auger-stem using the sample and vacuum lines and a removable length of 2-inch PVC pipe.

5. About 20 lbs of silica flour was mixed with water and installed through a tremie pipe in the annular space around the bottom of the sampler.

6. The lysimeter was held in place with the 2 -inch PVC pipe while water drained from the silica flour slurry (about 30 minutes).

7. A small quantity of native backfill was emplaced above the silica flour and, in turn, was overlain by approximately 25 lbs of $1 / 2$-inch-diameter bentonite pellets.

8. Water was added to cause the bentonite pellets to swell, forming a borehole seal above the lysimeter. 
9. The 2-inch PVC pipe was removed from the hole and the auger was carefully backed out of the hole so that placement of the sampler was not disturbed and access lines were not pinched.

10. The hole was backfilled with native materials to about $1 \mathrm{ft}$ below 1 and surface.

11. A lockable well protector constructed of 6inch-diameter steel casing surrounded by a small concrete pad was installed at the surface.

After installation, the lysimeters were pneumatically tested to reconfirm the integrity of the access tubes and all connections. Testing consisted of applying positive pressure to the pressure-vacuum line of each 1 ysimeter with a hand-operated pump, then observing a return flow of air from the sample line. The upper check valve was tested by applying pressure to the sample line and observing a rapid pressure buildup and no return flow from the other access line. After pressure testing each lysimeter, the hydraulic connection between the ceramic cup and the surrounding silica flour was tested by applying a vacuum and then discharging a water sample 24 hours later.

\section{Intake-Rate Testing of Lysimeters}

Intake-rate variability can affect the representativeness of lysimeter samples under conditions of varying solute concentration. Where solute concentrations are changing rapidiy, samples collected by lysimeters that acquire the largest fraction of the total sample volume at the beginning of an interval would differ from the samples collected by lysimeters with slower intake rates.

Intake-rate variability can also affect the representativeness of samples collected under conditions of rapidly varying solute concentration because of the influence of sample carryover. A small volume of sample remains in the lysimeter after a sample is discharged. The effect of sample carryover is greatest when a small volume is collected during subsequent sampling. Lysimeters with slow intake rates would contain smaller sample volumes during subsequent sampling and thus would be influenced more by sample carryover.

The samples collected with pressure-vacuum lysimeters may also be affected by the tendency to preferentially extract pore water at low soil tension from larger pores (England, 1974). The chemical composition of water in zones that have low soil tension because of high moisture content or in large pores may differ from that in zones that have high soil tension because of low moisture content or in micropores. The water in micropores is held by higher soil tension and may not be readily extractable.

Before the tracer test began, intake-rate testing was conducted to confirm the ability of the lysimeters to provide adequate sample volume 
in a short period of time so that changes in tracer concentration could be effectively monitored. During initial testing, the lysimeters were evacuated to a pressure of $-60 \mathrm{kPa}$, and the volumes of sample produced in 24- and 48-hour intervals were measured. The lysimeters were al so tested at a pressure of $-50 \mathrm{kPa}$ at time intervals of 6 and 20 hours to determine if a relation exists between intake rate and applied pressure.

When the six lysimeters were evacuated to a pressure of $-60 \mathrm{kPa}$, sample volume ranged from 400 to $510 \mathrm{~mL}$ (milliliters) after 24 and 48 hours (table 2 ). The lysimeters delivered sample volumes ranging from 80 to $490 \mathrm{~mL}$ when tested at a pressure of $-50 \mathrm{kPa}$ at time intervals of 6 and 20 hours (table 2). Four of the lysimeters-1, 3, 4, and 5 -showed only a slight decline in average sample volume at the higher pressure (less suction). The relation between intake rate and applied pressure for the six lysimeters is variable. All but two of the Iysimeters acquired most of the total sample volume in 6 hours or less. Lysimeters 2 and 6 were most affected by changes in sampling interval and applied pressure and were found to have slow intake rates and delivered proportionately more sample when tested at lower pressure (more suction). Lysimeters 2 and 6 may be acquiring less sample from fast-draining large pores-or zones where the soil tension is lower because the moisture content is higher-than the other lysimeters. Moisture content may have been lower near the intake section of lysimeters 2 and 6 so soil tension was higher. The differences in intake rate and sensitivity to changes in applied pressure may be caused by differences in soil texture and poresize distribution or moisture content in the immediate area of the lysimeter-intake section.

\section{UNSATURATED-ZONE TRACER TEST}

A pulse of reclaimed water containing an artificial tracer-bromide $\left(\mathrm{Br}^{-}\right)$- was monitored as it passed through the unsaturated zone beneath the test basin. Hater samples collected using lysimeters were analyzed for $\mathrm{Br}^{-}$concentrations, and tracer-breakthrough curves were prepared.

\section{Introduction of Tracer into Test Basin}

A chemical-feed pump was used to inject precise quantities of a solution having a $\mathrm{Br}^{-}$concentration of about $265,000 \mathrm{mg} / \mathrm{L}$ into the discharge line that conveyed reclaimed water from the treatment plant to the test basin. To conduct the tracer test, the pump was turned on when reclaimed water was being pumped into the basin.

The concentrated tracer solution was prepared by dissolving 800 lbs of granular potassium bromide $(\mathrm{KBr})$ in about 245 gal of water. A measured discharge rate for the chemical-feed pump and an estimated discharge rate for the reclaimed-water supply line were used to compute the concentration of $\mathrm{Br}^{-}$needed in the concentrated tracer solution to achieve the desired final $\mathrm{Br}^{-}$concentration. A motor-driven stirring 
Table 2.--Samole volumes extracted from lysimeters during intake-rate testing

\begin{tabular}{|c|c|c|c|c|c|}
\hline $\begin{array}{l}\text { Lysimeter } \\
\text { number }\end{array}$ & $\begin{array}{c}\text { Depth, } \\
\text { in } \\
\text { feet }\end{array}$ & $\begin{array}{l}\text { Time, } \\
\text { in } \\
\text { hours }\end{array}$ & $\begin{array}{c}\text { Applied } \\
\text { pressure, } \\
\text { in } \\
\text { kilopascals }\end{array}$ & $\begin{array}{l}\text { Sample } \\
\text { volume, } \\
\text { in } \\
\text { milli- } \\
\text { liters }\end{array}$ & $\begin{array}{l}\text { Sample in- } \\
\text { take rate, } \\
\text { in milli- } \\
\text { liters } \\
\text { per hour }\end{array}$ \\
\hline $\begin{array}{l}1 \\
2 \\
3 \\
4 \\
5 \\
6\end{array}$ & $\begin{array}{l}40 \\
27 \\
11 \\
27 \\
13 \\
45\end{array}$ & 48 & -60 & $\begin{array}{l}500 \\
410 \\
430 \\
480 \\
400 \\
440\end{array}$ & $\begin{array}{r}10.4 \\
8.5 \\
9.0 \\
10.0 \\
8.3 \\
9.2\end{array}$ \\
\hline $\begin{array}{l}1 \\
2 \\
3 \\
4 \\
5 \\
6\end{array}$ & $\begin{array}{l}40 \\
27 \\
11 \\
27 \\
13 \\
45\end{array}$ & 24 & -60 & $\begin{array}{l}510 \\
430 \\
420 \\
480 \\
400 \\
410\end{array}$ & $\begin{array}{l}21.3 \\
17.9 \\
17.5 \\
20.0 \\
16.7 \\
17.0\end{array}$ \\
\hline $\begin{array}{l}1 \\
2 \\
3 \\
4 \\
5 \\
6\end{array}$ & $\begin{array}{l}40 \\
27 \\
11 \\
27 \\
13 \\
45\end{array}$ & 20 & -50 & $\begin{array}{l}480 \\
200 \\
360 \\
420 \\
320 \\
300\end{array}$ & $\begin{array}{l}24.0 \\
10.0 \\
18.0 \\
21.0 \\
16.0 \\
15.0\end{array}$ \\
\hline $\begin{array}{l}1 \\
2 \\
3 \\
4 \\
5 \\
6\end{array}$ & $\begin{array}{l}40 \\
27 \\
11 \\
27 \\
13 \\
45\end{array}$ & 6 & -50 & $\begin{array}{r}490 \\
80 \\
360 \\
400 \\
340 \\
140\end{array}$ & $\begin{array}{l}81.7 \\
13.3 \\
60.0 \\
66.7 \\
56.7 \\
23.3\end{array}$ \\
\hline
\end{tabular}

device was used to keep the solution well mixed when the chemical-feed pump was in operation.

The tracer test was conducted in March and April 1987. At the beginning of the test, the water level in the test basin was allowed to drop as low as possible without exposing the basin bottom near the lysimeter cluster. This was done to avoid dilution and mixing problems when the tracer-laced reclaimed water was introduced into the basin. Estimated average remaining depth of water was $0.3 \mathrm{ft}$. A 5 -foot-wide 
strip of basin bottom was exposed around the edge of the basin. On March 30, 1987, tracer-laced reclaimed water was introduced into the basin, which filled in about 5 hours. During the next 4 days, the chemical-feed pump was used to inject tracer brine into the main discharge line whenever reclaimed water was being pumped into the basin to maintain a constant water level. At the end of the 4-day period, the water level in the basin was again allowed to drop as low as possible without exposing the basin bottom. The basin drained in 3.5 days and was then filled with reclaimed water containing no tracer. A constant water level was maintained throughout the remainder of the test.

\section{Sample Collection and Analysis}

After the infiltration basin was flooded with tracer-laced reclaimed water, a raw untreated sample was collected from each lysimeter and from the basin at 12-hour intervals from March 30 to April 29, 1987. Each time a sample was collected from a lysimeter, approximately $100 \mathrm{~mL}$ was discharged to waste before the sample bottle was filled. The procedure minimized sample carryover of water left in the discharge line from the previous sample. Basin samples were collected near the lysimeter cluster by slowly submerging a sample bottle held at an angle of about $30^{\circ}$ from vertical.

Water samples collected from the lysimeters and from the infiltration basin were analyzed to determine $\mathrm{Br}^{-}$content in a range of $10^{-5}$ to $10^{-3}$ molar concentration using a solid-state ion-selective electrode. The principles of measurement using an ion-selective electrode are analogous to the measurement of $\mathrm{pH}$ with the glass electrode. An ionselective electrode system consists of a sensing electrode (half-cell), a reference electrode (half-cell), a readout device (expanded-scale pH meter), and a sample solution. To minimize matrix interferences, samples and standards were brought to similar ionic strength by adding $2 \mathrm{~mL}$ of 5 molar sodium nitrate solution per $100 \mathrm{~mL}$ of sample or standard solution. Two standards were used to calibrate the instrument, and a third standard was used to confirm linearity of instrument response over the range of concentration being measured. After each group of 6 to 12 samples were analyzed, standards were rechecked to monitor for analytical drift. A reagent blank was analyzed along with each group of samples. Concentration of bromide in the reagent blanks was consistently below detection levels.

A variety of analytical techniques can be used in conjunction with an ion-selective electrode to increase sensitivity and minimize interferences. Information on the applications, analytical techniques, and limitations of ion-selective electrode procedures can be found in Skougstad and others (1975) and Orion Research'1 (1982).

1 The use of firm names in this report is for identification purposes only and does not constitute endorsement by the U.S. Geological Survey. 


\section{RESULTS OF STUDY}

The bromide-ion concentrations in water samples collected from the test basin were used to define the input of tracer-laced reclaimed water into the unsaturated zone. Tracer-breakthrough curves were prepared, and the bromide-ion concentration data from samples collected from the six lysimeters were examined to determine the maximum tracer concentration, time of first tracer arrival, and the rate of tracer movement through the unsaturated sediments at each sampling location. The temporal and spatial distributions of bromide-ion concentration in samples collected from the six lysimeters were interpreted to characterize the mechanism of flow and solute transport through the unsaturated zone at the site.

\section{Tracer Test}

Bromide-ion concentrations ranged from $2.0 \times 10^{-8}$ to $5.4 \times 10^{-4}$ molar in samples taken from the recharge basin. The concentrations of $\mathrm{Br}$ in samples collected from the recharge bas in before the introduction of tracer were below the detection level of the analytical method being used (about $2.0 \times 10^{-5}$ ). In the first 7.5 days of the tracer test, mean $\mathrm{Br}^{-}$ concentrations in the basin was $4.9 \times 10^{-4}$ molar $\left(S . D .=4.2 \times 10^{-5}\right)$. After the tracer-laced water drained from the basin, it was filled with water that did not contain tracer, and mean $\mathrm{Br}^{-}$concentration in the basin dropped to $4.6 \times 10^{-5}$ molar $\left(S . D .=2.5 \times 10^{-5}\right)$. Thus the tracer-laced water had a $\mathrm{Br}^{-}$concentration approximately one order-of-magnitude greater than the $\mathrm{Br}^{-}$concentration in the water in the basin before and after the test (fig. 3).

Tracer-breakthrough curves for all but one of the lysimeters at the site have a well-defined tracer maximum (fig. 4). The curves were developed by plotting relative $\mathrm{Br}^{-}$concentrations against elapsed time, in days, since the tracer was first introduced into the test basin. Relative concentration $\left(C / C_{0}\right)$ is a ratio obtained by dividing the $\mathrm{Br}^{-}$concentration in a sample $(C)$ by the mean $\mathrm{Br}^{-}$concentration in the tracer-laced water (Co). Tracer-breakthrough curves represent the combined effects of solute transport by advection and dispersion. Advection is the bulk movement of water; this movement carries solutes at the mean linear water velocity. Dispersion includes the processes of molecular diffusion and mechanical mixing. Dispersion causes solutes to spread out, both parallel and perpendicular to the flow direction, so that the rate of solute transport varies about the mean linear water velocity. In unsaturated porous materials, the diffusion of solutes into pores that are isolated from areas of active transport (dead-end pores) also contributes to dispersion (Nielsen and Biggar, 1961; Biggar and Nielsen, 1962; and Van Genuchten and cleary, 1982). Tracer-breakthrough curves for lysimeters 1 through 5 are roughly bel1 shaped. The curves exhibit a moderate degree of asymmetry and generally have a steeper slope on the rising leg (early time) than on the falling leg (1ater time). Samples from lysimeters 1 through 5 during the tracer test have maximum relative $\mathrm{Br}^{-}$concentrations that range from 0.70 to 0.90 (fig. 4). Bromide concentrations in samples from lysimeter 6 did not rise above background level during the 30-day sampling period. 


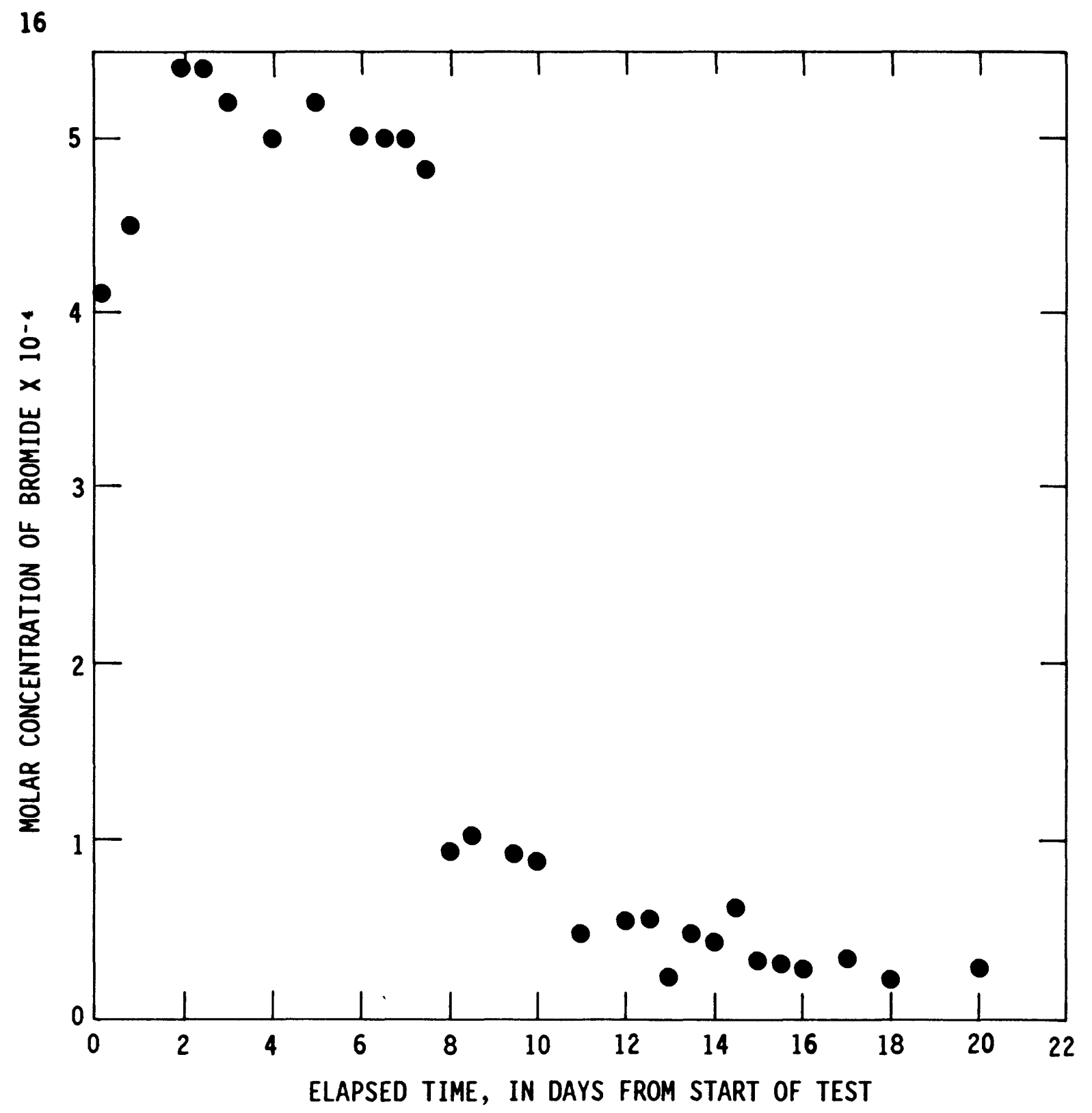

Figure 3.--Concentration of bromide $\left(\mathrm{Br}^{-}\right)$in basin 4 during tracer test. 


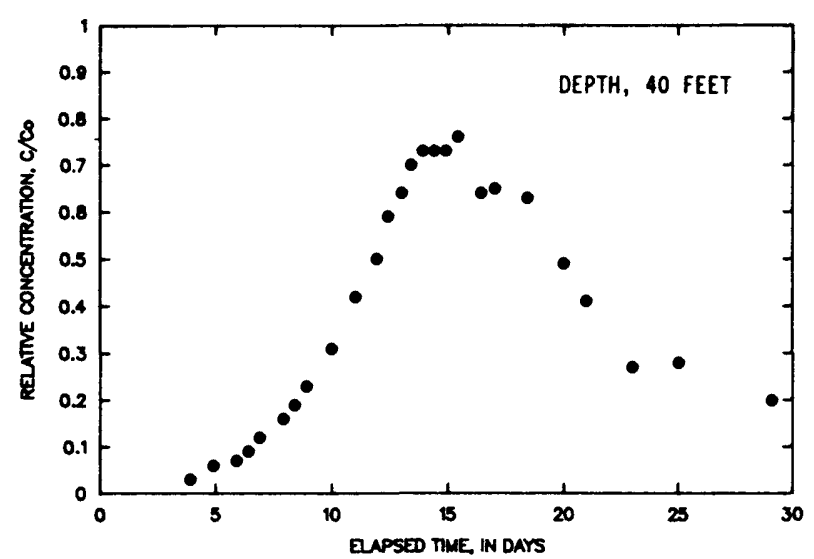

A. BROMIDE BREAKTHROUGH CURVE, LYSMETER 1

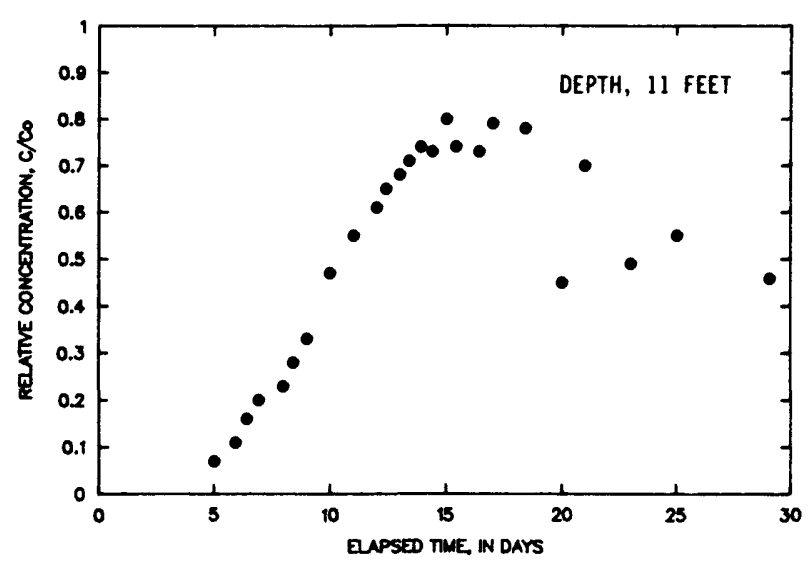

C. BROMIDE OREAKTHROUGH CURVE. LYSMETER 3

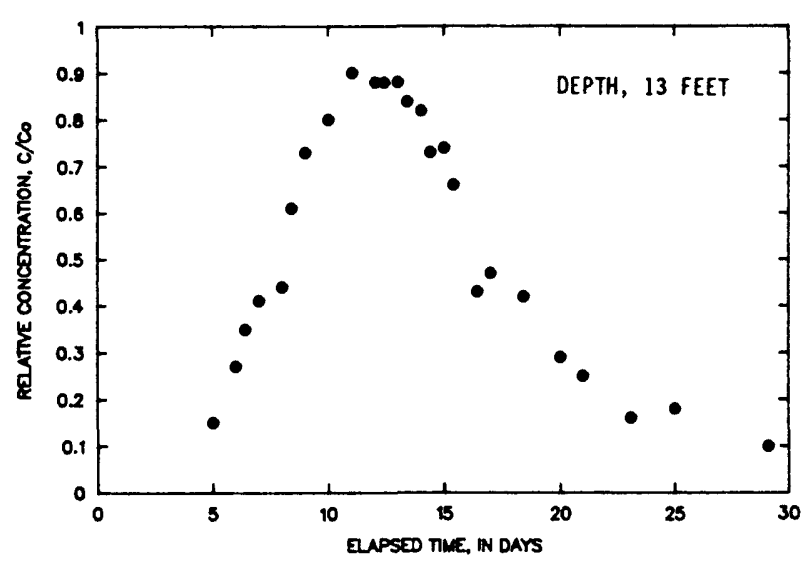

E. BROMIDE BREAKTHROUGH CURVE, LYSMETER 3

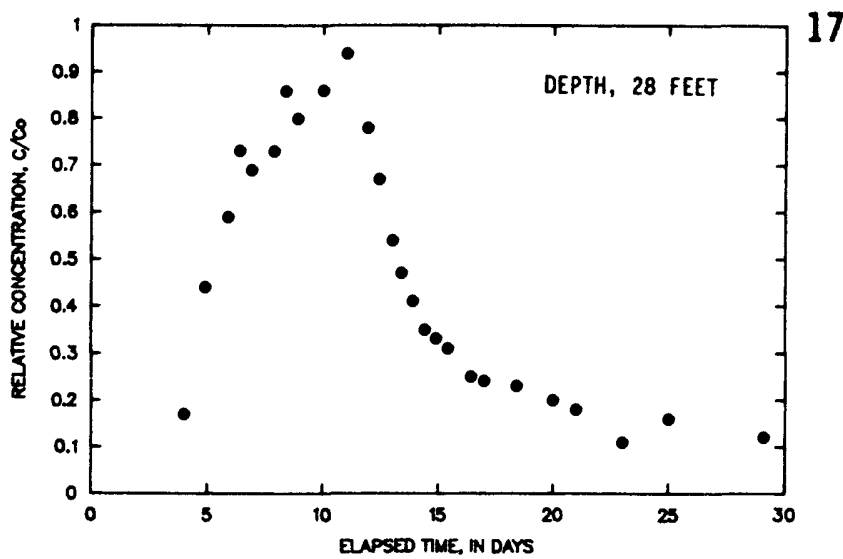

B. BROMIOE BREAKTHROUGH CURVE, IYSIMETER 2

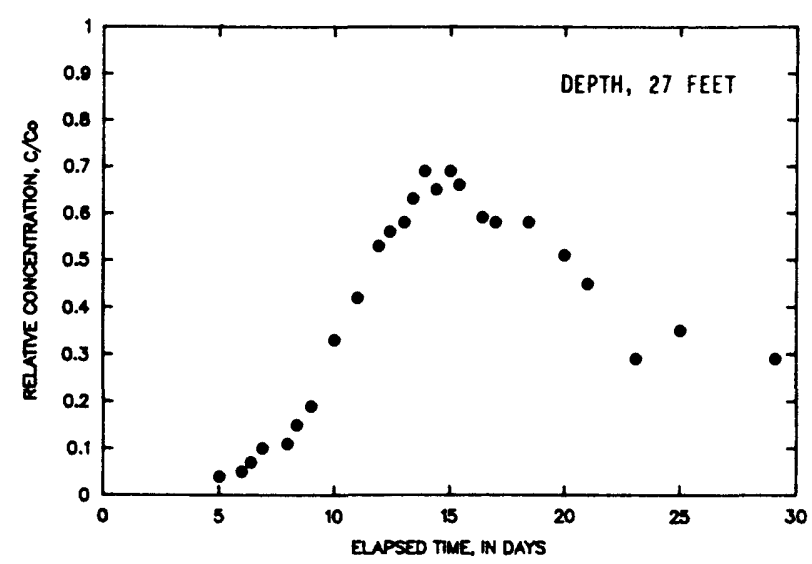

D. BROMIOE BREAKTHROUGH CURVE, LYSIMETER 4

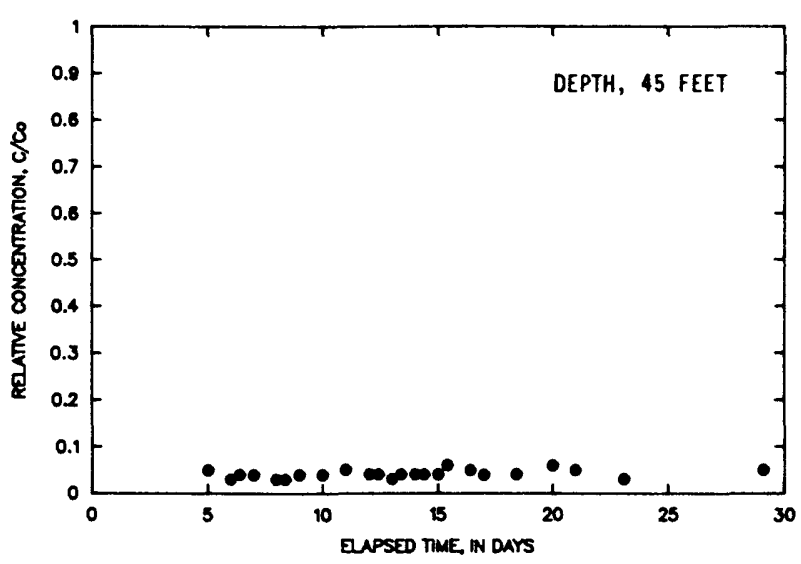

F. BROMIDE BREAKTHROUGH CURVE, IYSMETER 6

Figure 4.--Tracer-breakthrough curves. Relative concentration, $c / C_{0}$, is a ratio calculated by dividing the concentration of bromide in a sample by the bromide concentration in the water introduced into the test basin. 
Maximum bromide concentrations for all the lysimeters show no discernable relation to depth. For example, the peak $\mathrm{Br}^{-}$concentration at a depth of $11 \mathrm{ft}$ (lysimeter 3) is about the same as that found at a depth of $40 \mathrm{ft}$ (lysimeter 1), but the peak concentration at an intermediate depth of $13 \mathrm{ft}$ (1ysimeter 5) is noticeably larger.

The time of first arrival of the tracer represents flow through the most direct pathway between the basin bottom and the lysimeter and probably is controlled mainly by the process of advection. For consistency, time of first arrival was determined by finding the point on the tracer-breakthrough curve where a relative concentration of 0.1 was observed. In some cases, first arrival of the tracer occurred earlier at deep sampling locations than at shallow ones (table 3). For example, a relative concentration of 0.1 was observed at a depth of $27 \mathrm{ft}$ (lysimeter 2) about 3.1 days after the introduction of tracer into the recharge basin but not until about 5.8 days at a depth of only $11 \mathrm{ft}$ (lysimeter 3). Solute velocities in the proximity of these two iysimeters, computed from time of first arrival, are 9.0 and $1.9 \mathrm{ft} / \mathrm{d}$, respectively.

Dispersion is the spreading of a moving interface between two miscible fluids so that an initially sharp front becomes a gradual interface. The slope of the rising leg of a tracer-breakthrough curve can be interpreted as an indication of the amount of dispersion; a steeply sloping curve indicates less apparent dispersion than a gently sloping curve (Freeze and Cherry, 1979). The tracer-breakthrough curves for the lysimeters show no discernable relation between apparent dispersion and depth of sampling (fig. 4). The slope of the rising leg of the tracerbreakthrough curve for 1 ysimeter 1 (40 ft) is similar to that of Iysimeter $3(11 \mathrm{ft})$, but the slopes of the curves for lysimeters 2 and 5 , installed at intermediate depths $(27$ and $13 \mathrm{ft}$, respectively), are noticeably steeper (fig. 4).

\section{Interpretation of Results}

The arrival of tracer at deep sampling locations sooner than at shallow locations and the lack of any consistent relation between apparent dispersion and depth indicates that solute movement in the unsaturated zone beneath the test basin takes place along three-dimensional pathways rather than as a uniform wetting front. Flow may occur as discrete fingers in the coarse layers of the stratified sediments, or may follow large continuous voids such as interconnected macropores and fissures. Flow of this type is known as preferential flow. In this type of flow regime, downward moving water does not completely mix with or displace water in the stratigraphic profile or contact all the sediments in the profile. In preferential flow, downward-moving water may bypass a significant part of the water previously stored in the sediments and solutes may be transported more rapidly than if complete mixing had occurred (Starr and others, 1978). Palmquist and Johnson (1962) conducted an experiment that illustrates the difference between a wetting-front profile and a preferential-flow profile. The model tank used in their experiment (fig. 5) consisted of three layers ( $A, C$, and $E$ ) of 0.036 -millimeter glass beads (silt size) separated by two layers ( $B$ and $D$ ) 
Table 3.--Results of tracer test

[Maximum concentrations are expressed as relative concentrations $\left(C / C_{0}\right)$. Relative concentration is a ratio obtained by dividing the concentration of tracer in a sample by the concentration of tracer introduced into the test basin. Time of first arrival of tracer is obtained from breakthrough curves by noting the elapsed time when $c / C_{O}=0.1$ for each lysimeter. Velocity is computed by dividing the depth of the lysimeter by the observed time of first arrival]

\begin{tabular}{ccccc}
\hline $\begin{array}{c}\text { Lysimeter } \\
\text { number }\end{array}$ & $\begin{array}{c}\text { Depth, } \\
\text { in feet }\end{array}$ & $\begin{array}{c}\text { Maximum } \\
\text { concentration }\end{array}$ & $\begin{array}{c}\text { Time of first } \\
\text { arrival, in days }\end{array}$ & $\begin{array}{c}\text { Solute } \\
\text { velocity, in } \\
\text { feet per day }\end{array}$ \\
\hline 1 & 40 & 0.78 & 6.5 & 6.2 \\
2 & 28 & .95 & 3.1 & 9.0 \\
3 & 11 & .80 & 5.8 & 1.8 \\
4 & 27 & .70 & 7.0 & 3.8 \\
5 & 13 & .90 & 4.6 & 2.8 \\
6 & 45 & $(i)$ & & \\
\hline
\end{tabular}

1 Tracer not detected.

of 0.47 -millimeter glass beads (medium sand sized). The layers of glass beads were initially dry. Water that infiltrated from the top of the model moved as a wetting front through the fine-grained layers $A, C$, and $E$ at nearly equal vertical and horizontal velocities. Water moved vertically downward through the coarse-grained $B$ and $D$ layers along preferential flow paths as discrete small-diameter fingers. After 30 days of inflow, the visible water distribution in the coarse-grained layers was nearly the same as shown in figure 5-dry areas indicate that flow had bypassed much of the solid matrix in these layers.

Preferential flow in unsaturated materials, sometimes referred to as bypass, noncapillary, or gravitational macropore flow, has been observed in several other field and laboratory investigations. Preferential flow has been observed in seemingly homogeneous materials such as glass beads (DeSmedt and Wieranga, 1984; DeSmedt and others, 1986) and in stratified materials (Palmquist and Johnson, 1962; Starr and others, 1978) and has been known to occur under natural rainfall conditions (Lawes and others, 1882; Sharma and Hughes, 1985), in fields subject to trickle irrigation (Kies, 1981), and flood-irrigated conditions (Bowman and Rice, 1986b). Gelhar and others (1985) reviewed the results of many investigations relevant to field-scale solute-transport processes in unsaturated materials and concluded that flow and solute transport is a three-dimensional process, even in generally homogeneous materials and that lateral spreading and rapid gravity flow (along preferential pathways) are governing mechanisms. Preferential flow constitutes a mechanism by which solutes can be transported through the unsaturated zone bypassing sediments and water previously stored in the profile. 


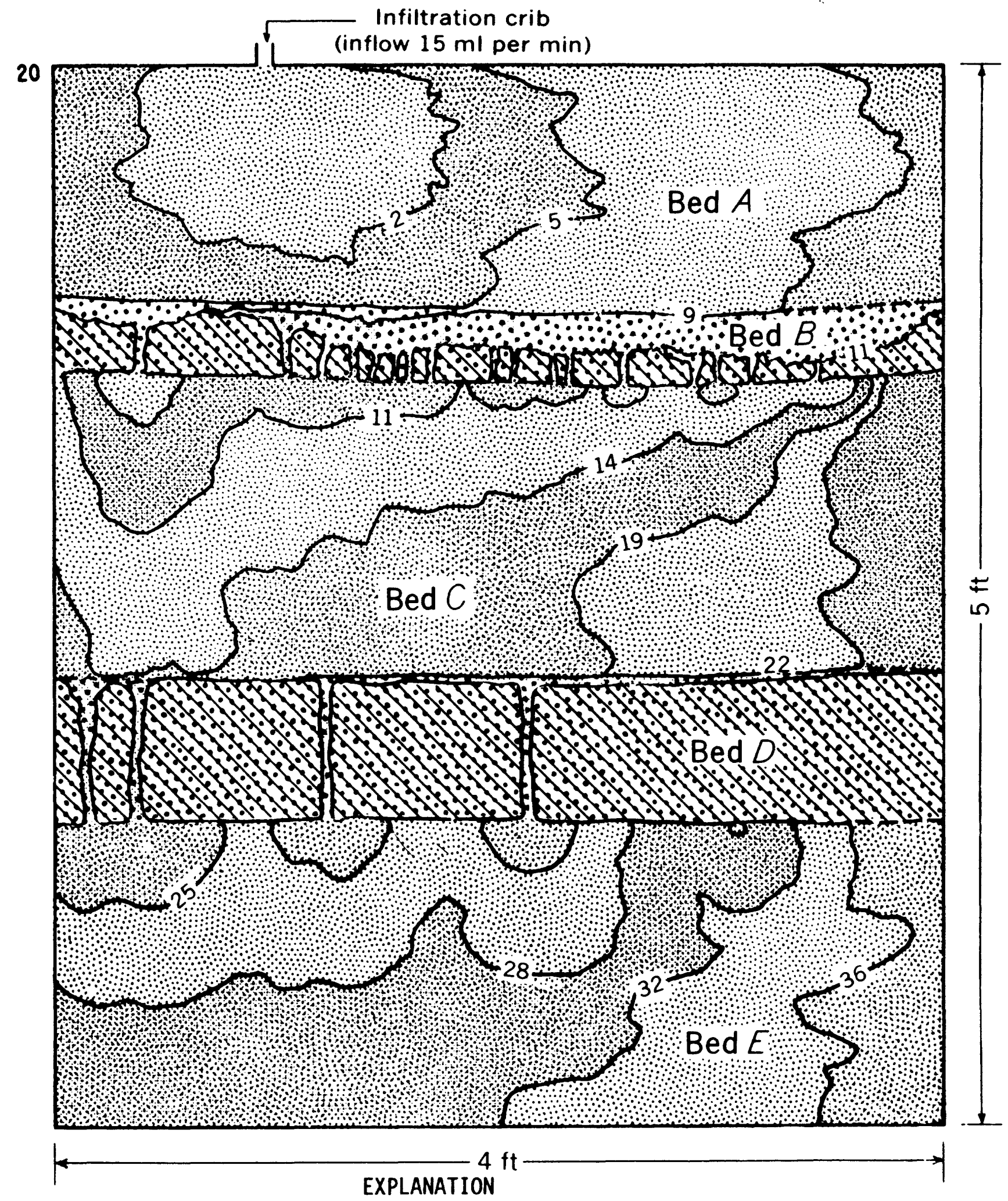

DRY AREAS IN COARSE-GRAINED LAYERS

Figure 5.--Cross section of model tank showing water movement as a wetting front and along preferential-flow paths through layered glass beads. Lines show position of wetting front after selected times of infiltration, in hours. Beds $A, C$, and $E$ are composed of 0.036 millimeter glass beads; beds $B$ and $D$ are composed of $0.47-$ millimeter glass beads. From Palmquist and Johnson, 1962, fig. 119.2. 
The hydraulic conductivity of an unsaturated granular material varies with moisture content. For a given material, hydraulic conductivity increases as moisture content increases. The exact relation between hydraulic conductivity and molsture content, however, varies with different materials. For example, at high moisture content, a coarse sand may have a higher hydraulic conductivity than clay but at low molsture content, the relation could be reversed-clay may have a higher hydraulic conductivity than coarse sand. Sediments at the recharge facility are stratified and heterogeneous with respect to grain size in both horizontal and vertical directions. Preferential flow could be a consequence of natural sediment heterogeneity. The flow follows more permeable paths and bypasses zones of low hydraulic conductivity (at the prevalling moisture content). Preferential flow causes some parts of the unsaturated zone to be bypassed, as evidenced by the absence of tracer in samples taken from lysimeter 6 . High relative concentrations $\left(C / C_{0}\right)$ in samples taken from iysimeters 1 to 5 indicate little mixing of the tracer-laced water with the water previously stored in the sediments of the unsaturated zone.

An alternative explanation for the irregular movement of water through the unsaturated zone is that short-circuiting may have occurred along the lysimeter access tubes. Although this possibility cannot be completely eliminated, the observed distribution of arrival time (table 3 ) makes it appear unlikely. If short-circuiting were occurring, the effect on velocity (table 3 ) should have been greatest at shallow depths. On the contrary, the distribution of velocity with depth (fig. 6) suggests that, in general, movement in the upper part of the profile is slower than movement in the lower part of the profile. Also, the absence of tracer in samples taken from lysimeter 6 cannot be explained by this alternative.

Flow in the unsaturated zone is influenced by capillary forces and gravity. In dry conditions (high soil tension), particularly in layered sediments, capillary forces may dominate and cause extensive lateral water movement (Yeh and GeThar, 1983; Yeh and others, 1982). In conditions of high moisture content (low soll tension), gravity becomes the more dominant force. When initial water content is high and the water-application rate is rapid, lateral water movement may be minimal, even in stratified sediments (Prill, 1977). In such cases gravitational forces may exceed capillary forces and water may move rapidly in saturated channels of small diameter. Several conditions are present at the Tucson recharge facility that are especially conducive to preferential flow in the unsaturated zone:

- High rate of water application-a constant-head upper boundary (ponding).

- High initial moisture content in much of the unsaturated profile because of the cyclic use of the recharge basins.

- Layered sediments-fine-grained stratified sediments overlying coarser sediments.

- Poorly sorted, heterogeneous sediments throughout the unsaturated zone. 


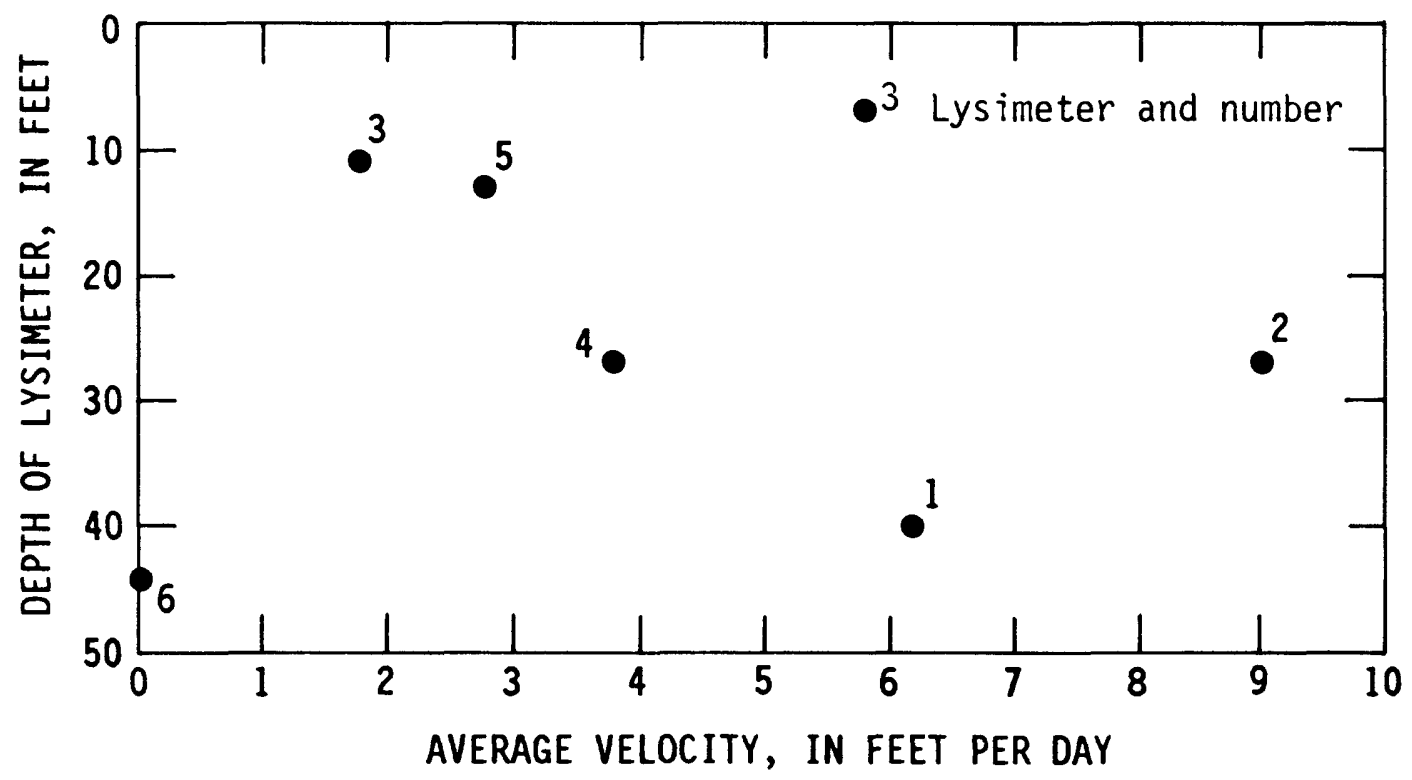

Figure 6.--Distribution of average velocity computed from tracerbreakthrough curves with depth in the unsaturated zone. 
Low moisture content and the presence of stratified layers, especially in the upper 10 to $20 \mathrm{ft}$ of the unsaturated profile, probably cause lateral flow to occur when water is first introduced into a recharge basin after an extended dry period. As inundation continues and the fine-grained stratified materials at the top of the profile approach saturation, the force of gravity will exceed the capillary forces and water will flow into the underlying coarse-grained materials. Movement of water into the coarse-grained lower layers probably occurs only after the capacity of the fine-grained overlying materials to disperse the water laterally by capillary action is exceeded. Downward movement through the upper fine-grained materials is slow, initially because of lateral movement and later because of the presence of lenses of materials having low hydraulic conductivity. Gravity flow through the lower coarse-grained materials is probably more rapid and occurs along preferential pathways-that is, not as a uniform wetting front.

\section{SIGNIFICANCE OF RESULTS}

Preferential flow allows solutes to move rapidly through the unsaturated zone (Starr and others, 1978; Thomas and others, 1978). Under such conditions, contaminants from the 1 and surface will arrive at the water table sooner than would be expected if flow were assumed to occur as a uniform wetting front that pushes ahead of it water previously stored in the pores of the unsaturated sediments (miscible-displacement theory). Most of the water stored in the soll profile is not involved under conditions where preferential flow prevails (Lawes and others, 1882; Bowman and Rice, 1986a) and less interaction will occur between recharge water and the solid matrix of the unsaturated zone. A consequence of preferential flow is that soluble chemicals applied at the land surface may be moved to a greater depth by rain or irrigation than would be predicted by the miscible-displacement theory (Bowman and Rice, 1986b; Thomas and Phillips, 1979; Thomas and others, 1978). Soluble chemicals in the unsaturated profile may be bypassed and remain near the land surface when the rate of liquid addition is low, such as in most areas of Tucson basin and other arid or semiarid regions. In arid and semiarid regions, this condition may be partly responsible for the large concentrations of soluble chemicals commonly found in the unsaturated zone. Practices such as artificial recharge that increase the rate of liquid addition may eventually mobilize the soluble chemicals and cause deterforation of ground-water quality. Also, any contaminants contained in the recharging water could move to the water table. The large concentrations of nitrate and sulfate in ground water near the area of the major streams of Tucson basin (Laney, 1972) is evidence that the relatively high rate of liquid addition in these areas is mobilizing soluble salts in the unsaturated profile or that these constituents are present in large concentrations in the recharge water and are moving to the water table under natural conditions.

Chemicals thought to be readily attenuated by adhesion to soil particles or microbially mediated degradation reactions in the upper part of the unsaturated zone may pass to the water table, bypassing much of the sediment, because of preferential flow. Where the flow of water is 
concentrated into fingers or channels, the renovating capability of soil is reduced because of the smaller surface area exposed to the water and reduced contact time in the biologically active part of the profile (Shaffer and others, 1979; Thomas and Phillips, 1979). If adsorption sites are bypassed, organic chemicals could move to greater depths where they might pose a threat to ground water. Substances such as chlorinated hydrocarbons (TCE, pesticides, and herbicides), other refractory organic compounds (detergents and humic substances), and microorganisms (viruses and bacteria) could pass into the underiying ground water (Germann and others, 1987; Jury and others, 1986; Walker, 1973; Ongerth and others, 1973; Robertson and others, 1974). This potential for contamination of ground water would be great where rates of liquid addition are high, such as near streams or ponds. In these areas, the presence of a thick unsaturated zone may not prevent the eventual (and perhaps rapid) migration of a contaminant to the regional ground-water system.

\section{SUMMARY}

A tracer test was conducted in March and April 1987 at an artificial-recharge facility operated by the City of Tucson. The test was done to determine the mechanism of flow that controls solute transport through the thick layers of poorly sorted alluvial sediments that constitute the unsaturated zone in Tucson basin. Water samples were collected from the unsaturated zone using porous-cup, pressure-vacuum lysimeters installed at depths ranging from 11 to $45 \mathrm{ft}$ below the bottom of a 3/4-acre recharge basin.

Well-defined tracer peaks were observed for all but one of the six lysimeters installed at the site. Maximum tracer concentration showed no consistent relation with depth. In some cases, tracer arrival occurred earlier in deep sampling locations than in shallow ones. Velocity of solute flow computed from time of first tracer arrival-representing flow through the most direct pathways-ranges from 1.9 to $9.0 \mathrm{ft} / \mathrm{d}$. Apparent dispersion, as indicated by the slope of the rising leg of each tracer-breakthrough curve, showed no relation to depth. The experiment results indicate that water movement in the unsaturated zone beneath the recharge basin takes place along preferential-flow paths rather than as a uniform wetting front. Preferential flow may be a consequence of natural sediment heterogeneity $\longrightarrow$ with flow following paths having the highest hydraulic conductivity at the prevailing moisture content. Less interaction occurs between recharge water and solid-phase materials in the unsaturated zone under preferential-flow conditions, and the recharge water does not completely mix with or displace water previously stored in the unsaturated profile. Preferential flow allows solutes to move rapidly through the unsaturated zone. Substances that normally would be decomposed by microbial action or sorbed by sediment particles can move through the unsaturated zone and cause contamination of the regional ground-water system under preferential-flow conditions. Substances such as organic solvents, pesticides, detergents, humic acid, and bacteria could cause ground-water contamination under these conditions. 


\section{REFERENCES CITED}

Anderson, S.R., 1987, Cenozoic stratigraphy and geologic history of the Tucson basin, Pima County, Arizona: U.S. Geological Survey Water-Resources Investigations Report 87-4190, $20 \mathrm{p}$.

Biggar, J.W., and Nielsen, D.R., 1962, Miscible displacementII. Behavior of tracers: Soll Science Society of America Proceedings 26, p. 125-128.

Bowman, R.S., and Rice, R.C., 1986a, Accelerated herbicide leaching from preferential flow phenomena and its implication for groundwater contamination, in Proceedings of the Conference on Southwestern Ground Water Issues, October 20-22, 1986, Tempe, Arizona: Dublin, Ohio, National Water Well Association, p. 313-425.

1986b, Transport of conservative tracers in the field under intermittent flood irrigation: American Geophysical Union, Water Resources Research, v. 22, p. 1531-1536.

Davidson, E.S., 1973, Geohydrology and water resources of the Tucson basin, Arizona: U.S. Geological Survey Water-Supply Paper 1939-E, $81 \mathrm{p}$.

DeSmedt, F. and Wieranga, P.J., 1984, Solute transfer through columns of glass beads: American Geophysical Union, Water Resources Research, v. 20, no. 2, p. 225-232.

DeSmedt, F., Wauters, F., and Sevilla, J., 1986, Study of tracer movement through unsaturated sand: Amsterdam, Holland, Elsevier Science Publ ishers, Journal of Hydrology, v. 85, no. 1/2, p. 169-181.

Ecology and Environment, Inc., 1986, Phase I data summary report, Phoenix-Litchfield Airport area remedial investigation: San Francisco, California, Ecology and Environment, Inc., v. 1, $65 \mathrm{p}$.

England, C.B., 1974, Comments of "A technique using porous cups for water sampling at any depth in the unsaturated zone" by Warren $W$. Wood: American Geophysical Union, Water Resources Research, v. 10 , no. 6, p. 1049.

Everett, L.G., and McMillion, L.G., 1985, Operational ranges for suction Iysimeters: Ground Water Monitoring Review, Summer 1985, v. 5, no. 3 , p. 51-60.

Fenneman, N.M., 1931, Physiography of Western United States: New York, McGraw-Hill, $534 \mathrm{p}$.

Freeze, R.A., and Cherry, J.A., 1979, Groundwater: Englewood, New Jersey, Prentice-Hall, $604 \mathrm{p}$. 
Gelhar, L.W., Mantoglou, A., Welty, C., and Rehfeldt, K.R., 1985, A review of field-scale physical solute transport processes in saturated and unsaturated porous media: Palo Alto, California, Electric Power Research Institute Report EA-4190, 103 p.

Germann, P.F., Smith, M.S., and Thomas, G.H., 1987, Kinematic wave approximation to the transport of Escherichia Coli in the vadose zone: American Geophysical Union, Hater Resources Research, v. 23, no. 7, p. 1281-1287.

Hargis and Montgomery, Inc., 1982a, Phase I-Investigation of subsurface conditions in the vicinity of abandoned waste disposal sites, Hughes Aircraft Company Manufacturing Facility, Tucson, Arizona: Tucson, Arizona, Harg is and Montgomery, Inc., v. 1, 11, and 111, v.p.

$1982 \mathrm{~b}$, Phase II-Investigation of subsurface conditions in the vicinity of abandoned waste disposal sites. Hughes Aircraft Company Manufacturing Facility, Tucson, Arizona: Tucson, Arizona, Hargis and Montgomery, Inc., v. 1, 11, and 111, v.p.

Johnson, R.B., 1987, City of Tucson groundwater recharge programs, in Third Symposium on Artificial Recharge of Groundwater in Arizona, Phoenix, Arizona, May 20-21, 1987: Phoenix, Arizona, Salt River Project report, p. 123-130.

Jury, H.A., Elabd, Hesham, Resketo, Margaret, 1986, Field study of napropamide movement through unsaturated soil: American Geophysical Union, Water Resources Research, v. 22, no. 5, p. 749-755.

Kies, Bouziane, 1981, Solute transport in unsaturated field soil and in ground water: Las Cruces, New Mexico, New Mexico State University, Ph.D dissertation, $353 \mathrm{p}$.

Laney, R.L., 1972, Chemical quality of the water in the Tucson basin, Arizona: U.S. Geological Survey Water-Supply Paper 1939-D, $46 \mathrm{p}$.

Lawes, J.B., Gilbert, J.H., and Warington, R., 1882, On the amount and composition of the rain and drainage waters collected at Rothamsted: London, Royal Agricultural Society of England Journal, v. 18, p. 1-71.

Leake, S.A., and Hanson, R.T., 1987, Distribution and movement of trichloroethylene in ground water in the Tucson area, Arizona: U.S. Geological Survey Water-Resources Investigations Report 86-4313, $40 \mathrm{p}$.

Mock, P.A., Travers, B.C., and Williams, C.K., 1985, Results of the Tucson Airport area remedial investigation-Phase I, Volume 2, Contaminant transport modeling: Arizona Department of Water Resources duplicated report, $106 \mathrm{p}$. 
Nielsen, D.R., and Biggar, J.W., 1961, Miscible displacement-I. Experimental Information: Madison, Wisconsin, Soil Science Society of America Proceedings 25, p. 1-5.

Ongerth, H.J., Spath, D.P., Crook, James, and Greenberg, A.E., 1973, Public health aspects of organics in water: Denver, Colorado, Journal of the American Water Works Association, July, p. 495.

Orion Research, 1982, Handbook of electrode technology: McGaw Park, Illinois, American Scientific Products, $45 \mathrm{p}$.

Palmquist, W.N., and Johnson, A.I., 1962, Vadose flow in layered and nonlayered materials: U.S. Geological Survey Professional Paper 450-C, p. 142-143.

Prill, R.C., 1977, Movement of moisture in the unsaturated zone in a loess-mantled area, southwestern Kansas: U.S. Geological Survey Professional Paper 1021, $21 \mathrm{p}$.

Randa11, R.A., and Johnson, B.R., 1985, A demonstration recharge in Arizona, May 2-3, 1985: Tucson, Arizona, University of Arizona, Water Resources Research Center, p. 252-262.

Robbins, G.A., and Gemme11, M.M., 1985, Factors requiring resolutions in installing vadose zone monitoring systems: Ground Water Monitoring Review, Summer 1985, v. 5, no. 3, p. 75-80.

Robertson, J.M., Toussaint, C.R., and Jorque, M.A., 1974, Organic compounds entering ground water from a landfill: U.S. Environmental Protection Agency Report EPA-660/2-74-077, $47 \mathrm{p}$.

Sellers, W.D., Hill, R.H., and Sanderson-Rae, Margaret, eds., 1985, Arizona cl imate-The first hundred years: Tucson, Arizona, University of Arizona Press, $80 \mathrm{p}$.

Shaffer, K.A., Fritton, D.D., and Baker, D.F., 1979, Drainage water sampling in a wet, dual pore system: Madison, Wisconsin, Journal of Environmental Quality, v. 8, p. 241-246.

Sharma, M.L., and Hughes, M.W., 1985, Groundwater recharge estimation using chloride, deuterium, and oxygen-18 profiles in the deep coastal sands of western Australia: Amsterdam, Holland, Elsevier Science Publishers, Journal of Hydrology, v. 81, no. $1 / 2$, p. 93-109.

Skougstad, M.W., Fishman, M.J., Friedman, L.C., Erdmann, D.E., and Duncan, S.S., 1975, Methods for determination of inorganic substances in water and fluvial sediments: U.S. Geological Survey Techniques of Water-Resources Investigations, book 5, chap. Al, 626 p.

Starr, J.L., DeRoo, H.C., Frink, C.R., and Parlange, Y.R., 1978, Leaching characteristics of a layered field: Madison, Wisconsin, Journal of the Soil Science Society of America, v. 42, no. 3, p. 386-391. 
Thomas, G.W., and Phillips, R.E., 1979, Consequences of water movement in macropores: Madison, Wisconsin, Journal of Environmental Quality, v. 8, no. 2, p. 149-152.

Thomas, G.H., Phillips, R.E., and Quisenberry, V.L., 1978, Characterization of water displacement in soils using simple chromatographic theory: Oxford, England, Journal of Soil Science, v. 29, p. 32-37.

U.S. Environmental Protection Agency, 1984, Final determination of ground water system of the Upper Santa Cruz basin and Avra-Altar basin of Pima, Pinal, and Santa Cruz Counties, Arizona-Aquifer determination: Federal Register, v. 49, no. 16, OW-FRL-2511-3, p. 2948-2950.

1986, Permit guidance manual for unsaturated zone monitoring for hazardous waste land treatment units: U.S. Environmental Protection Agency Report EPA/530-SW-86-040, 145 p.

1988, Cleanup of TCE contaminated groundwater, Tucson Airport Superfund site: U.S. Environmental Protection Agency Fact Sheet No. 4, February 1988, $8 \mathrm{p}$.

Van Genuchten, M.T., and Cleary, R.W., 1982, Movement of solutes in soil-Computer-simulated and laboratory results, in soil Chemistry B. Physico-Chemical Models: New York, ETsevier Scientific Publishing Co., p. 349-386.

Walker, W.H., 1973, Where have all the toxic chemicals gone?: Dublin, Ohio, National Water Well Association, Ground Water, v. 7, no. 1, p. 9-16

Yeh, T.-C., and Gelhar, L.W., 1983, Unsaturated zone in heterogeneous soils, in Mercer, J.W., and others, Role of the unsaturated zone in radioactive and hazardous waste disposal: Ann Arbor, Michigan, Ann Arbor Science, p. 71-79.

Yeh, T.-C., Ge1har, L.W., and Gutjahr, A.L., 1982, Stochastic analys is of effects of spatial variability on unsaturated flow: Socorro, New Mexico, New Mexico Institute of Mining and Technology Report $\mathrm{H}-12,228 \mathrm{p}$. 